Central Washington University

ScholarWorks@CWU

All Faculty Scholarship for the College of the Sciences

$11-7-2017$

Exploring the Historical Earthquakes Preceding the Giant 1960

Chile Earthquake in a Time-Dependent Seismogenic Zone

Marco Cisternas

Matias Carvajal

Robert Wesson

Lisa L. Ely

Nicolás Gorigoitia

Follow this and additional works at: https://digitalcommons.cwu.edu/cotsfac

Part of the Geology Commons, and the Geophysics and Seismology Commons 


\title{
Exploring the Historical Earthquakes Preceding the Giant 1960 Chile Earthquake in a Time-Dependent Seismogenic Zone
}

\author{
by M. Cisternas, M. Carvajal, R. Wesson, L. L. Ely, and N. Gorigoitia
}

\begin{abstract}
New documentary findings and available paleoseismological evidence provide both new insights into the historical seismic sequence that ended with the giant 1960 south-central Chile earthquake and relevant information about the region's seismogenic zone. According to the few available written records, this region was previously struck by earthquakes of varying size in 1575,1737 , and 1837 . We expanded the existing compilations of the effects of the two latter using unpublished first-hand accounts found in archives in Chile, Peru, Spain, and New England. We further investigated their sources by comparing the newly unearthed historical data and available paleoseismological evidence with the effects predicted by hypothetical dislocations. The results reveal significant differences in the along-strike and depth distribution of the ruptures in 1737, 1837, and 1960. While the 1737 rupture likely occurred in the northern half of the 1960 region, on a narrow and deep portion of the megathrust, the 1837 rupture occurred mainly in the southern half and slipped over a wide range of depth. Such a wide rupture in 1837 disagrees with the narrow and shallow seismogenic zone currently inferred along this region. If in fact there is now a narrow zone where 200 years ago there was a wider one, it means that the seismogenic zone changes with time, perhaps between seismic cycles. Such change probably explains the evident variability in both size and location of the great earthquakes that have struck this region over the last centuries, as evidenced by written history, and through millennia, as inferred from paleoseismology.
\end{abstract}

Electronic Supplement: First-hand written accounts of the 1737 and 1837 earthquakes, method to compute the tidal level on the 1837 earthquake's day, hypothesis to explain the minor local effects of the 1837 tsunami, modeling results for each of the 1837 earthquake's hypothetical sources, and nineteenth-century maps.

\section{Introduction}

The largest earthquake instrumentally recorded, the giant 1960 Chile earthquake ( $\left.M_{\mathrm{w}} 9.5\right)$, seemingly overspent its plate-tectonic budget. It ruptured nearly $1000 \mathrm{~km}$ of the Chilean subduction zone where the Nazca and South American plates converge at $6.6 \mathrm{~m}$ per century (Angermann et al., 1999; Fig. 1a). The slip, which averaged 20-30 m over the length of the rupture (Plafker and Savage, 1970; Cifuentes, 1989 ) and up to $40 \mathrm{~m}$ locally (Barrientos and Ward, 1990; Moreno et al., 2009), expended about 350 years' worth of plate motion. Yet as judged from the scarce historical accounts of damage, the slip area ruptured at least partially only 123 years before, in 1837, and also at earlier intervals of 100 and 158 years, in 1737 and 1575 (Lomnitz, 1970).

To understand this budgetary imbalance and then the enormity of the 1960 earthquake, the spatial distribution of the slip released by its predecessors should be addressed. This issue deserves special attention today because the 1960 region seems to have seismically reawakened (Ruiz et al., 2017), and future great earthquakes are expected to occur (Moreno et al., 2011). However, this task is hindered by the scarcity of reports on the effects produced by the 1575, 1737, and 1837 earthquakes. Historical circumstances affected the production and geographic distribution of written records. Archives for this region go back to the middle of the sixteenth century, but they are scarce for the seventeenth and eighteenth centuries, and they provide no coverage along the southern half of the 1960 rupture area (Cisternas et al., 2005). For example, while the 1575 historical earthquake is a well-documented event, the later 1737 earthquake has previously only been known through two secondary sources-a 
(a)
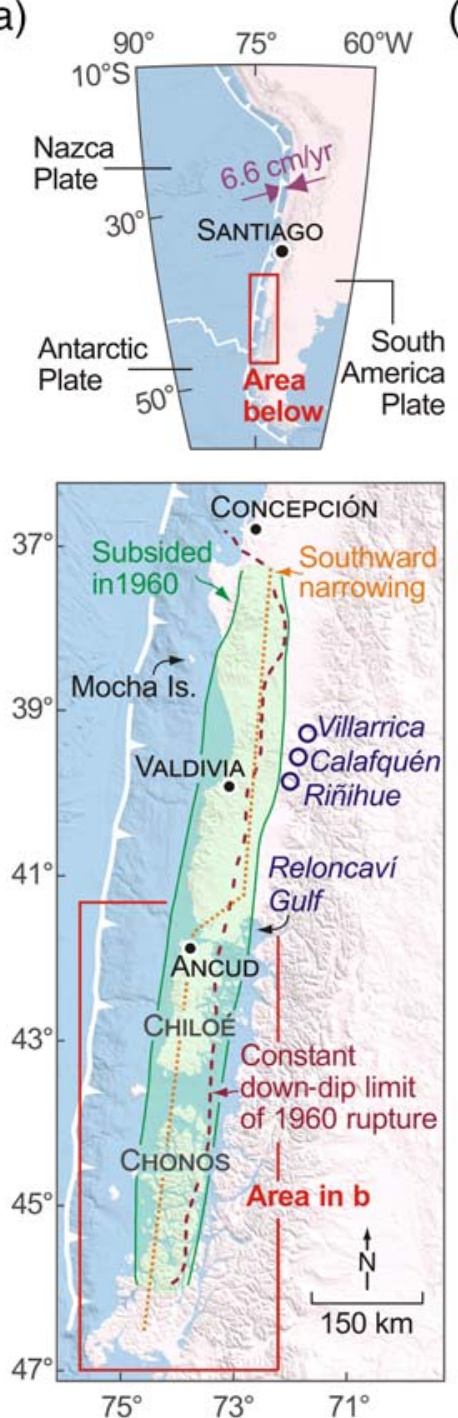

(b)



(c)

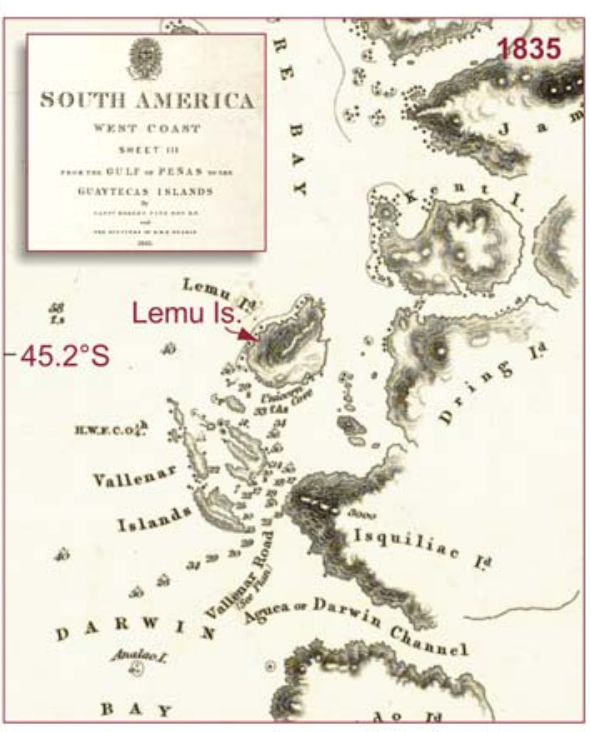

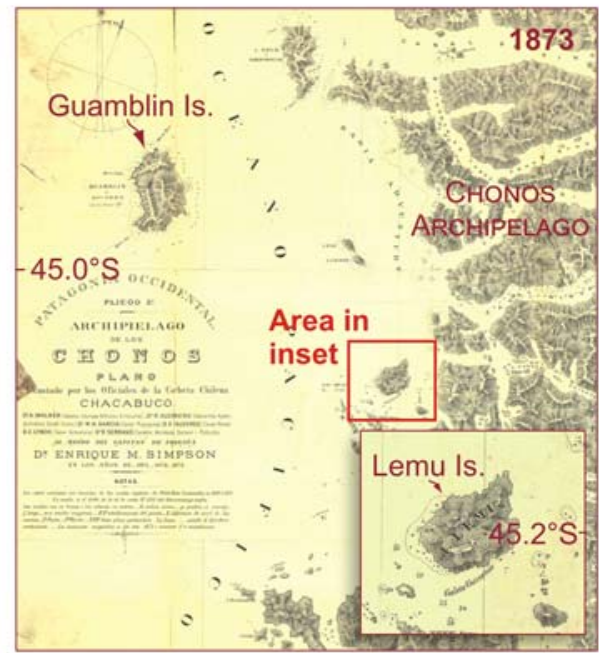

Figure 1. Index maps. (a) Plate-tectonic setting of Chile and the 1960 earthquake region. Paired arrows indicate plate convergence at $6.6 \mathrm{~cm} / \mathrm{yr}$ (Angermann et al., 1999) and transparent area shows region that subsided tectonically (Plafker and Savage, 1970). The dashed line shows a constant down-dip limit for the 1960 rupture (Moreno et al., 2009); dotted line delineates the hypothetical southward narrowing of the megathrust seismogenic zone (Wang et al., 2007; Volker et al., 2011). Open circles show the lakes mentioned in the text. (b) Southern half of the 1960 earthquake region. Geophysical profile of Isla Chiloé from Volker et al. (2011). Note that Lemu Island in the south is located within the subsided area in 1960. The star shows the Chilean Seismological Center's hypocenter of the Melinka 2016 earthquake. (c) Section of the chart by Section of the chart made by FitzRoy in 1835, the most accurate map of the Chonos Archipelago available by 1837, which depicts Lemu; the island described as uplifted in 1837 by French whalers (above). Note that Lemu Island at $45.2^{\circ} \mathrm{S}$ is not to be confused with the larger and more well-known Lemuy Island off the east coast of Chiloé at $42.6^{\circ} \mathrm{S}$. Part of the chart "Archipielago de los Chonos" made in 1873 by Enrique Simpson from the Chilean Navy (below). He was one of the Chilean officers with a mandate that extended beyond hydrography into natural history. As in FitzRoy's chart, Simpson correctly identifies and locates Lemu Island (inset). Is., island. The color version of this figure is available only in the electronic edition.

pair of history books written five decades later by authors who did not witness the event.

We sought to improve this situation by expanding the existing compilations of the effects produced by the 1737 and 1837 events within the region of the 1960 earthquake. By mining colonial archives in Chile, Peru, and Spain, we found a dozen primary sources that clarify the extent of damage caused by the 1737 shaking. We also augmented the cata- $\log$ of written records of shaking, land-level changes, and a tsunami associated with the 1837 earthquake. To cover the uninhabited southern half of the 1960 region, we scrutinized logbooks of whalers who visited the area at the time of the 1837 earthquake and reports from Chilean surveyors who mapped the area later in the nineteenth century. We also checked for first-hand contemporary accounts of flooding and damage in Japan that might be ascribed to tsunamis from south-central 
Chile. We further investigated the sources of the 1737 and 1837 earthquakes by comparing the newly unearthed historical data and the published paleoseismological evidence with the effects predicted by hypothetical dislocations at multiple depth ranges.

The 1960 Earthquake and Associated Seismotectonic Assumptions

On 21 and 22 May 1960, an astonishing series of earthquakes broke the boundary between the subducting Nazca plate and the overriding South America plate (Cifuentes, 1989; Fig. 1a,b). The series culminated in a compound, partly aseismic, rupture that likely changed Earth's rotational wobble (Kanamori and Cipar, 1974). The seismic mainshock, of magnitude 9.5, lowered one-quarter of Chile's outer coast by a meter or two (Plafker and Savage, 1970). Concurrent displacement of the seafloor generated a tsunami with peak heights of $15 \mathrm{~m}$ in Chile (Sievers, 1963), $10 \mathrm{~m}$ Hawaii (Eaton et al., 1961), and $6 \mathrm{~m}$ in Japan (Watanabe, 1998).

The distribution of slip during the 1960 rupture has been estimated through associated land-level changes and dislocation models. These land-level changes, measured eight years later, extended along a trench-parallel belt $1000 \mathrm{~km}$ long and $200 \mathrm{~km}$ wide, characterized by subsidence along the coast and uplift of the continental shelf and offshore islands (Plafker and Savage, 1970). Using these geodetic data and a dislocation model with planar geometry, Barrientos and Ward (1990) inferred a main rupture area $900 \mathrm{~km}$ long and $150 \mathrm{~km}$ wide. Most of the slip, between 20 and $30 \mathrm{~m}$ and peaking at $40 \mathrm{~m}$, was confined between the trench and the coast, but some extended down-dip to a depth of 80-110 km. Moreno et al. (2009) used the same data in a finite-element model with a more realistic nonplanar fault geometry. They derived a similar slip distribution, but with almost all the slip confined to the region between the trench and a constant lower limit just inland of the coast at a depth of about $40 \mathrm{~km}$ along the entire $900 \mathrm{~km}$ rupture (Fig. 1a,b).

Along-strike variations of the width of the seismogenic zone along the 1960 region have been proposed on the basis of postseismic deformation and thermal models. The southward decrease in the velocity of landward motion of the coastal sites shown by post-1960 Global Positioning System (GPS) observations has been explained by a southward narrowing of the seismogenic zone along the 1960 region (Wang et al., 2007). Such narrowing is in full agreement with the thermal model of Volker et al. (2011), being ascribed to the southward decrease of the age along the Nazca plate, in which an increasingly younger subducting plate produces a warmer thermal regime, moving the up-dip and downdip limits of the seismogenic zone gradually closer together (Volker et al., 2011). However, if the thermal modeling includes other variables, such as hydrothermal circulation within the oceanic crust and frictional heating on the plate interface, the results do not show the narrowing; instead, they support a constant width of the seismogenic zone along the entire 1960 region (Rotman and Spinelli, 2014).

If the down-dip limit of the 1960 rupture were in fact constant, the southward decrease of the landward GPS velocities would be alternatively explained by a southward decrease in the amount of coseismic slip in 1960 (Wang et al., 2007). This assumes that the zone of relocking roughly matches that where coseismic slip occurred. However, decadal GPS observations in the area suggest that the plate interface accumulates elastic strain (and slip deficit) in a spatially and temporally variable mode. The current distribution of locking indicates that the cores of the 1960 asperities are already relocked, suggesting that the locking state and therefore the stress accumulation can also vary with time (Moreno et al., 2011).

The recent $2016 M_{\mathrm{w}} 7.6$ Chiloé earthquake struck the previously quiescent southern half of the 1960 region (Melgar et al., 2017; Ruiz et al., 2017; Xu, 2017). It ruptured a highly locked area in southern Chiloé, near the bottom of the seismogenic zone as currently defined by plate coupling models. It is argued that the rupture resulted from changes in the interseismic locking produced by the interaction between the readjustment of the mantle flow after the 2010 Maule earthquake and a sudden end of the post-1960 mantle relaxation (Ruiz et al., 2017). As with the 1960 event, but at a much smaller scale, the 2016 Chiloé earthquake appears to have also exceeded the slip deficit theoretically accumulated since 1960 (Melgar et al., 2017). Notably, this implies that even the largest earthquake ever recorded may not have used all the available slip.

\section{The Historical Predecessors of the 1960 Earthquake}

The 1960 earthquake was preceded historically by earthquakes of varying size in 1575,1737 , and 1837 . The reported effects of the 1575 earthquake and tsunami most nearly resemble those in 1960. In 1575 shaking damaged Spanish settlements for $640 \mathrm{~km}$ from Concepción south to Castro on Chiloé Island and triggered landslides that blocked the outlet of Riñihue Lake in the Andean foothills (Lomnitz, 1970; Fig. 1a). Conquistadors reported persistent marine inundation from north of Valdivia to Castro, implying widespread tectonic subsidence (Cisternas et al., 2005). The associated tsunami took more than 1000 lives in small Indian communities around Valdivia and wrecked galleons in that city's port. Despite these similarities with the 1960 event, there is no known account of a 1575 tsunami in Japan (Watanabe, 1998). A subsequent earthquake in 1737 , until now only known from two secondary sources, damaged Valdivia and towns on Isla Chiloé but produced no reported tsunami. The 1837 earthquake damaged towns along the central third of the 1960 rupture area and changed land levels along the southern half of that area (Lomnitz, 1970). The height of the ensuing tsunami, reportedly cresting $6 \mathrm{~m}$ high in Hawaii (Coan, 1882), suggests that the 1837 earthquake released almost half of the seismic moment of the 1960 mainshock (Abe, 1979). 


\section{Sources and Limitations of the Historical Accounts}

Written history in Chile begins in the middle of the sixteenth century, when Spaniards first colonized Santiago and vicinity (Cisternas et al., 2012). As the conquistadors pushed southward, the Indians began an intermittent insurgency that lasted into the nineteenth century. At first the colonists set up seven outposts in south-central Chile, including Concepción and Valdivia on the mainland and Castro on Isla Chiloé (Fig. 1a,b). All these towns were in the northern half of the 1960 rupture area, and they all produced reports of the 1575 earthquake and tsunami. However, in 1598, a widespread Indian uprising drove the colonists from most of these outposts (Torrejón et al., 2004). At the time of the 1737 earthquake, the Spanish were still restricted to Concepción, Valdivia, and Castro, and these are the only places that provide accounts of this earthquake.

Chilean independence in 1810 and the waning of the Indian insurgency re-established extensive record keeping along the northern half of the 1960 region before the earthquake and tsunami of 1837. Although the new Republic lacked presence south of Chiloé, whalers had begun visiting the Chonos Archipelago by the end of the eighteenth century (Pereira Salas, 1971; Fig. 1b,c). Those from France, Holland, Denmark, and Great Britain were followed by whalers from the northeastern United States, chiefly between 1825 and 1860 (Greve, 1948). By that time, three of the most important Pacific whaling grounds were located off Mocha Island, Guafo Island, and the Chonos Archipelago (Clark, 1887; Fig. 1b,c). Whaling captains kept logbooks of daily entries on location, weather, captures, and work onboard, along with occasional entries for unusual events, which included reports of the 1837 earthquake as felt at sea and its onshore effects. Another captain, the well-known Robert FitzRoy, commander of HMS Beagle during Darwin's famous voyage, charted Chiloé and the western coast of the Chonos Archipelago in 1835, shortly before the 1837 earthquake (Fig. 1c and (E) Fig. S1a in the electronic supplement to this article). Additional information came to light later in the nineteenth century when the Chilean Navy made surveys for nautical charts of the area south of Chiloé (Fig. 1b and (E) Fig. S1b). With a mandate that extended beyond hydrography into natural history, the surveyors linked the 1837 earthquake to some of what they saw and heard.

Tsunamis generated off Chile and Peru also entered written history by crossing the Pacific Ocean and coming ashore in Japan, particularly along the Sanriku coast of northeast Honshu. The main examples between the sixteenth and nineteenth centuries are the tsunamis that came from Peru in 1586, 1687, and 1868 and from Chile in 1730, 1751, 1837, and 1877 (Watanabe, 1998; Atwater et al., 2005). The 1960 tsunami from south-central Chile took 138 lives in Japan, chiefly in Sanriku. Historical circumstances, however, also limit the completeness of the Japanese catalog of South American tsunamis. Throughout the centuries before 1600 , the written records are sparse or refer mainly to central
Honshu (Ueda and Usami, 1990). The records did not become both widespread and numerous until the era of stability under the Tokugawa shoguns, between 1603 and 1867, fortunately supplementing the sparse records from south-central Chile after the 1598 Indian insurrection.

\section{Paleoseismological Evidence for the 1737 and 1837}

Events

Previous paleoseismological studies provide additional evidence of the 1737 and 1837 earthquakes, including signs of shaking, land-level changes, and tsunami inundation.

Turbidites in lakes Villarrica $\left(39.25^{\circ} \mathrm{S}\right)$, Calafquén $\left(39.52^{\circ} \mathrm{S}\right)$, and Riñihue $\left(39.83^{\circ} \mathrm{S}\right)$ in the northern half of the 1960 region (Fig. 1a) indicate shaking at these latitudes in 1737 and 1837 (Moernaut et al., 2014). However, the spatial distribution of the turbidites among the lakes suggests a more northerly location for the 1737 earthquake and a more southerly location for the 1837 event. A marine turbidite in the Gulf of Reloncaví, located $200 \mathrm{~km}$ to the south of the lakes $\left(41.72^{\circ} \mathrm{S}\right.$; Fig. 1a), and triggered by the 1837 earthquake (St-Onge et al., 2012), also supports a more southerly location for this event. At a similar latitude, but on the open western coast of Chiloé, at Cocotué (41.92 ${ }^{\circ} \mathrm{S}$; Fig. 1b), a series of soils buried locally by debris flows and extensively by tsunami sand sheets recorded the occurrence of both great and smaller earthquakes and tsunamis during the last 1000 years. Although the series includes evidence for shaking and tsunami inundation in 1837, it lacks evidence for the 1737 event (Cisternas et al., 2017). Similarly, a 5500-year-long coastal lacustrine record of tsunamis, also facing the open western coast of Chiloé at Huelde Lake $\left(42.60^{\circ} \mathrm{S}\right.$; Fig. 1b), shows evidence of the 1837 tsunami but none for 1737 (Kempf et al., 2017).

Other studies made at nearby sites, but in more protected settings, show coastal evidence of subsidence and tsunami inundation only for the 1960, 1575, and older prehistoric events (Cisternas et al., 2005; Atwater et al., 2013; Garret et al., 2015). Notably lacking in these latter stratigraphic records are the 1737 and 1837 events.

Additional evidence for the presence or absence of landlevel changes in 1837 comes from trees. Drowned forests of dead or dying trees at San Rafael Fjord (46.59 $\mathrm{S}$; Fig. 1b), at the southern end of the 1960 rupture, suggest $2 \mathrm{~m}$ of subsidence in 1837 (Reed et al., 1988). Absence or little vertical change in 1837 was inferred from old-growth trees at Pudeto, an estuary in northern Chiloé (41.87 $\mathrm{S}$; Bartsch-Winkler and Schmoll, 1993) and at Misquihué, on the mainland along the

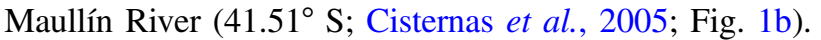

\section{Methods}

\section{Archives}

We sought additional written records of the 1737 and 1837 earthquakes in the Archivo Nacional in Chile, Archivo de la Nación in Peru, Archivo General de Indias in Spain, 

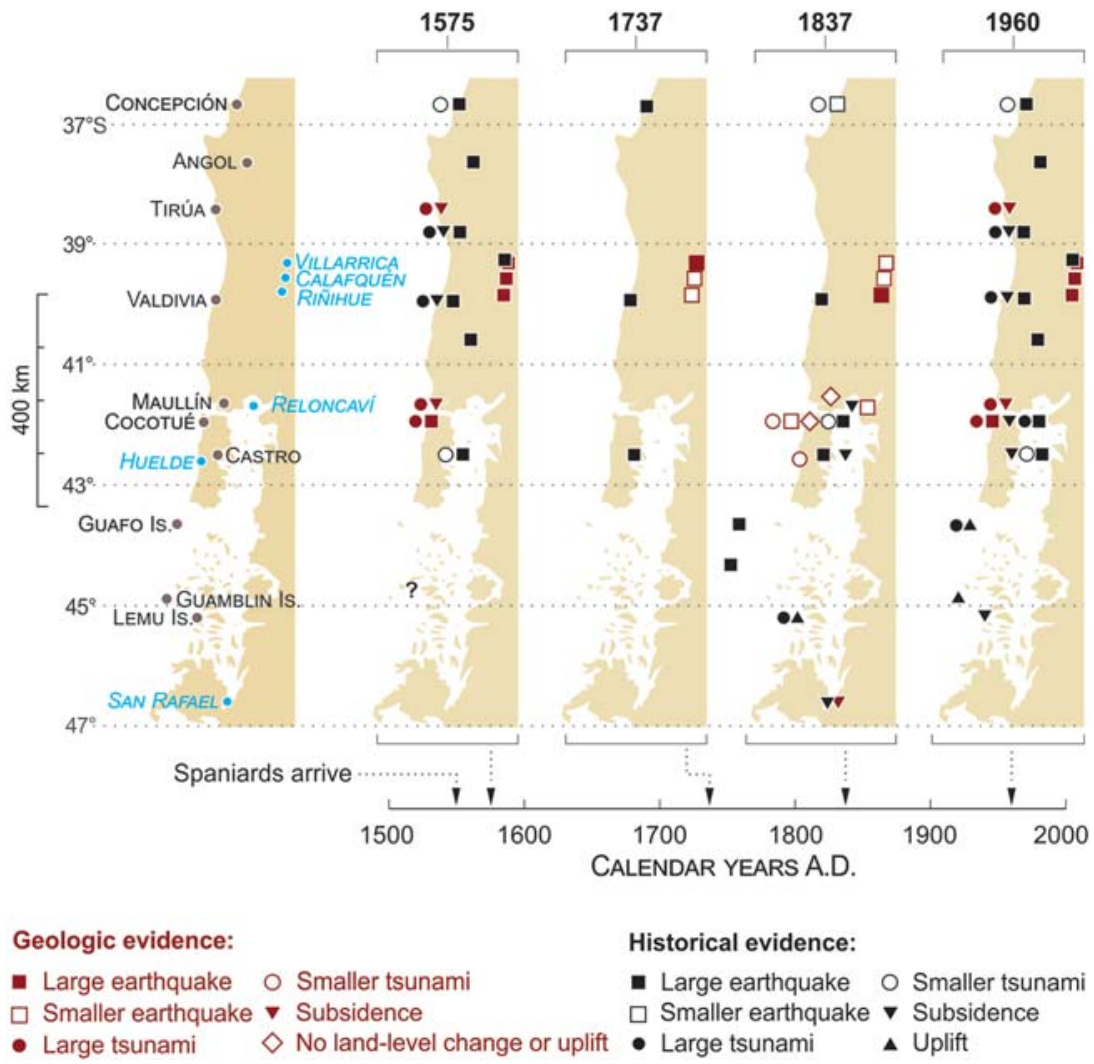

Figure 2. Graphical summary of the compiled evidence for the 1575-1960 earthquake sequences along the length of the 1960 region. Plot of the geologic and historical evidence for each event. Geologic evidence from Cisternas et al. (2005), Ely et al. (2014), Moernaut et al. (2014), Garrett et al. (2015), Cisternas et al. (2017), and Kempf et al. (2017). Historical evidence from Lomnitz (1970), Cisternas et al. (2005), and this study. The color version of this figure is available only in the electronic edition.

sitivity results from the relatively short distance between the coast and the trench, where the shallow slip mainly controls tsunami generation while deeper slip is generally required to raise the coast (Carvajal and Gubler, 2016). On this basis, we conducted simple forward-modeling tests to investigate the rupture depth required to match the pattern of both land and seafloor deformation (i.e., tsunami size) inferred from the compiled historical and paleoseismological evidence.

To this end, we computed the surface deformation patterns and subsequent transpacific tsunamis produced by four hypothetical ruptures of varying depth. We considered three narrow megathrust ruptures, characterized by shallow (7-25 km depth), intermediate (25-43 km depth), and deep (43-61 km depth) slip, and a wide one represented by the dislocation of the entire megathrust seismogenic zone (7-61 km depth). The width and geometry of the seismogenic zone was obtained from geophysical studies conducted in south-central Chile (Volker et al., 2011; Rotman and Spinelli, 2014). We considered a wide seismogenic zone extending from the buried trench to about $60 \mathrm{~km}$ depth below sea level. Such a wide seismogenic zone is in agreement with the thermally inferred seismogenic zone

and in New England whaling archives in the United States. The Archivo Nacional, the main historic archive of Chile, maintains the country's most complete collection of original colonial manuscripts. Because Chile was a dependent territory of colonial Peru in 1737, we also examined the Peruvian archives in the Archivo de la Nación. Spain's Archivo de Indias holds 40,000 documents, with some 80 million pages in all, about the Spanish colonial administration of the Americas and the Philippines. The Peabody Essex, Falmouth, and New Bedford whaling museums hold logbooks of U.S. whaling ships that sailed along the southern coast of Chile during the nineteenth century. Additionally, we checked for first-hand contemporary accounts of flooding and damage in Japan that might be ascribed to tsunamis from south-central Chile.

\section{Depth of Slip in 1837: Model Setup}

Beyond the inference of a southern location for the 1837 earthquake drawn above, we attempted to constrain the depth range of its coseismic slip. We took advantage of the strong sensitivity of both land-level changes and tsunami generation to the depth of slip along the Chilean megathrust. This sen- by Rotman and Spinelli (2014), which roughly matches that of Volker et al. (2011) if the transitional zone is included. For simplicity, we represented the curved megathrust geometry by a planar fault dipping at $18.5^{\circ}$, according to the average dip angle of the local megathrust (Volker et al., 2011). Based on the along-strike extent of the reported land-level changes, we considered minimum rupture lengths of $500 \mathrm{~km}$, extending from northern Chiloé to the southern limit of the 1960 rupture. Because of the imprecision of the currently available evidence, all tested ruptures assume a unit amount of uniform slip. For the same reason, we did not attempt to estimate the amount of 1837 slip.

Finally, tsunami simulations across the Pacific Ocean basin were conducted for each hypothetical rupture. The initial tsunami waveforms were inferred from the seafloor deformation due to earthquake faulting (Okada, 1985). The tsunami propagations were computed using the linear longwave approximation and a finite-difference method (Liu et al., 1998; Wang, 2009) on General Bathymetric Chart of the Oceans (GEBCO) bathymetry, with a grid size of 30 arcsec. All simulations were run for $30 \mathrm{hrs}$. 


\section{Written Records of the 1737 and 1837 Earthquakes}

In this section, we summarize new and previous documentary information about the 1737 and 1837 earthquakes (Fig. 2). Details, including quotations in extenso from the newly found original documents and bibliographic sources, are in (E) Text S1.

\section{The 1737 Earthquake}

We found 12 first-hand accounts of the 1737 event that complement the two secondary sources previously available. The accounts, found in the Archivo Nacional in Chile and Archivo de Indias in Spain, show that the 1737 earthquake damaged buildings along the strike of the subduction zone for $640 \mathrm{~km}$ (Fig. 2).

Notably, two of these accounts extend the area of 1737 earthquake damage far north to Concepción, where the cathedral was so badly damaged that it was subsequently demolished. The Bishop of Concepción told the King about the damage to his cathedral: “...with the earthquake that this City and Bishopric suffered, the connections of the building came apart, removing the support that they provided, and the walls were tilted out...." A second manuscript, a letter sent by Chile's governor to the King, also refers to the Concepción cathedral: "With the formidable earthquake... the material of the building of this holy cathedral church suffered to the extent that it was left in a useless state..., it was expedient, even necessary to disassemble it... indeed this diligence was carried out...."

Eight of the new primary sources confirm great damage in Valdivia. The city's fortresses, temples, royal storehouse, and walls were completely destroyed, as were its riverside docks.

In Chiloé, two sources report that the 1737 earthquake destroyed the main church of Castro. When the auxiliary Bishop of Concepción visited Castro four years after the earthquake, he tells: “...this inclement climate has prevented me... building the church... in the city of Castro... because the parish was ruined by the earthquake of the year [17]37...." Later his secretary wrote in another document: " ... his lordship went to the shack that was serving as a church... the priests did not give a reason other than that the church... was ruined by the earthquake of the year [17] thirty-seven...."

Although the 1737 earthquake damaged buildings along the great distance that separates Concepción from Castro, written evidence for an associated tsunami is notably lacking, from both Chile and Japan. If there was a Pacific Ocean tsunami associated with the 1737 earthquake, it must have been quite small. None of the 12 accounts mentions unusual seas, even though some are testimonies focused on shaking damage to buildings fringing the shoreline. Other reports describe the effects of the earthquake, but not of a tsunami, at places where tsunamis associated with later earthquakes caused significant damage. No tsunami in 1737 is reported in the written records in Japan, even though an era of political stability under Tokugawa shoguns yielded Japanese written records of transpacific tsunamis that came from Peru in 1687, Cascadia in 1700, Valparaíso in 1730, and Concepción in 1751 (Watanabe, 1998; Atwater et al., 2005).

\section{The 1837 Earthquake and Tsunami}

In contrast to the 1737 earthquake, much is known about the event that struck south-central Chile on 7 November 1837 at 8 a.m. (Cisternas et al., 2005). In Concepción, Valdivia, and Ancud, intendentes (provincial governors) set down eyewitness accounts of the earthquake and the ensuing tsunami. South of Chiloé, newly found and previously overlooked evidence from whaling logbooks indicates that shaking, land-level changes, and tsunami effects extended southward into the Chonos Archipelago (Fig. 1b,c).

Shaking from the 1837 earthquake was felt for $800 \mathrm{~km}$ between Concepción and the Chonos Archipelago (Fig. 2). In Concepción, which had been relocated inland after the 1751 tsunami, the 1837 earthquake was felt rather strong (Cisternas et al., 2005), but unlike in 1737, there was no reported damage. In Valdivia, shaking was much stronger than in Concepción and people were thrown off balance. Its fortresses were destroyed again, as in 1737, and the roads were impassable due to ground cracks, fallen trees, and landslides. Profuse landslides were also reported in Chiloé, along with fallen trees and ground failures. It was reported that millstones jumped off their seats and plowed-under grass rotated upright in potato fields (Cisternas et al., 2005). A previously overlooked source reports strong shaking south of Chiloé, off Guafo Island at $43.63^{\circ} \mathrm{S}$ (Fig. 1b), when the masts of the French whaling ship l'Ocean, commanded by Simon Coste, were violently shaken by the 1837 earthquake. The southernmost evidence of shaking in 1837 comes from another, newly found, whaler account (Fig. 3). The master of the U.S. whaling ship Ohio, Charles Coffin, felt at 8 a.m. two shocks within 15 min while sailing off the Chonos Archipelago at $44.17^{\circ} \mathrm{S}-76.33^{\circ} \mathrm{W}$. A third shock was recorded the next day at 8 p.m.

The 1837 earthquake was accompanied by land-level changes along the southern half of the 1960 earthquake rupture area, from the latitude of Ancud southward to San Rafael Fjord (Fig. 1b). One month after the earthquake, l'Ocean anchored at Lemu, a western island of the Chonos Archipelago $\left(45.20^{\circ} \mathrm{S}-74.52^{\circ} \mathrm{W}\right)$. Captain Coste, who had visited the island before the earthquake, found the anchorage $2.5 \mathrm{~m}$ shallower. The uplift was evident as rocks, previously always submerged, were then exposed. A large quantity of still decomposing shellfish convinced him that the emergence was recent. A second overlooked source, perhaps including Coste's testimony but based on additional witnesses as it uses the plural "several captains," also describes uplift in the Chonos. Joseph du Bouzet, hydrographer of a French exploration expedition that visited Chile early in 1838 (Dumont d'Urville, 1842), reports that several French whaling captains working in the Chonos told him that soon after the 1837 earthquake, the islands in the archipelago were found to have been raised. Whalers described the rocky point of a bay that they fre- 
(a)

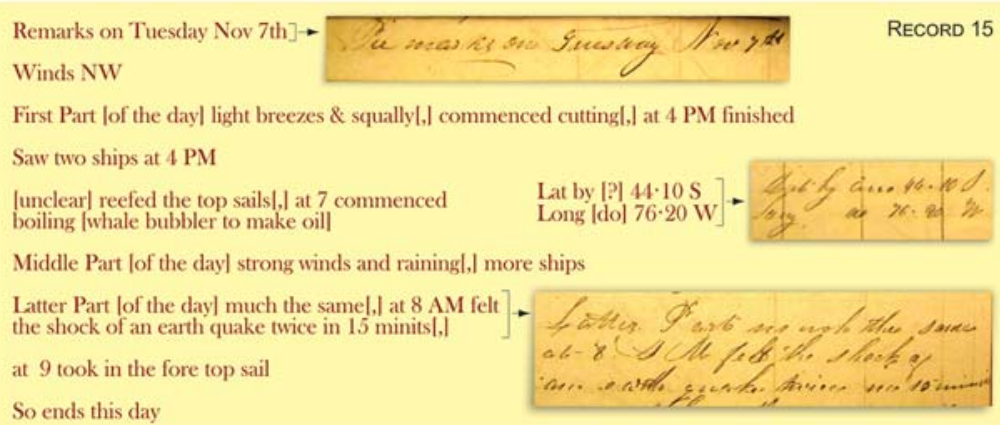

(b)

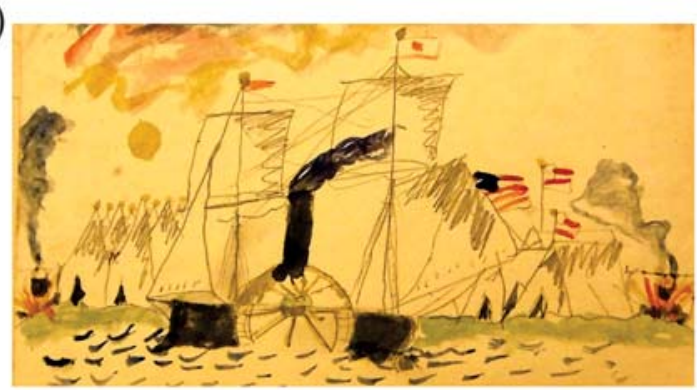

(c)

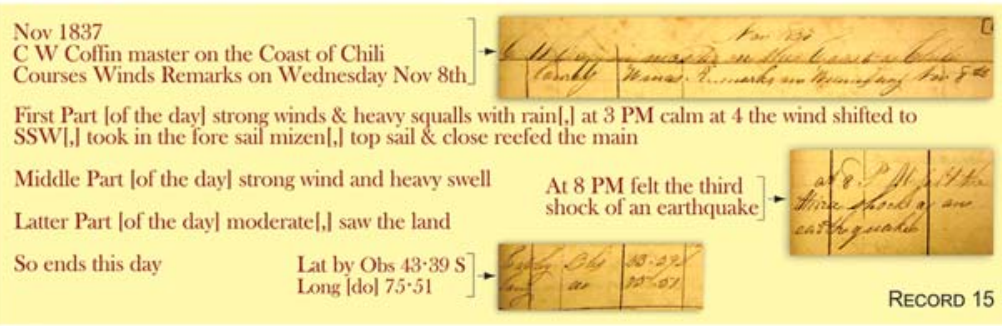

Figure 3. Southernmost evidence of shaking in 1837. Account from the logbook of the U.S. whaling ship Ohio, registered in Nantucket and skippered by Charles Coffin, the author of the log. The logbook was found in the New Bedford Whaling Museum, New Bedford, Massachusetts. (a) Entry on the day of the earthquake, 7 November 1837. Although the ship was sailing off the Chonos Archipelago $\left(44.17^{\circ} \mathrm{S}-76.33^{\circ} \mathrm{W}\right), \sim 50 \mathrm{~km}$ west of the trench on the Nazca plate, Coffin recorded two shocks in 15 min at 8 a.m. (b) Drawing included in Coffin's logbook showing a whaling campsite with tents and fires to boil blubber. An early U.S. side-wheel paddle steamer stands out in the foreground. (c) The next day, Coffin reported an aftershock at 8 p.m. while sailing northward off Guafo Island. The color version of this figure is available only in the electronic edition.

quented as covered for a long distance with mussels, limpets, and other shellfish that were discomposing but still attached to the rocks. These accounts of uplift reported by the whalers in Lemu Island and the Chonos Archipelago in 1837 contrast notably with the subsidence reported in this region associated with the 1960 earthquake. In 1960, Lemu subsided $0.5 \mathrm{~m}$ and most of the archipelago subsided more than $1 \mathrm{~m}$ (Plafker and Savage, 1970). The opposing sense of land-level change in this region is a fundamental difference between the 1837 and 1960 earthquakes.

Additional information about land-level changes in 1837, which could include postseismic signals, was obtained in the latter part of the nineteenth century, when the Chilean Navy was charting Chiloé and the Chonos Islands (Fig. 1c and (E) Fig. S1). At Guar Island $\left(41.69^{\circ} \mathrm{S}\right)$, where land level was unchanged in 1960, surveyor Francisco Vidal Gormaz in 1871 found that tides were flooding land that had been arable before. The residents told him that this subsidence resulted from the 1837 earthquake. Similarly, at Tac Island $\left(42.39^{\circ}\right.$ S: Fig. $1 b$ and () Fig. S1a), where the level of the land probably did not change in 1960 , a clergyman in the 1890s found trunks from old trees that were still in growth position yet were flooded by high tides. In still another account, collected by Vidal Gormaz from a local ship's pilot who was in the Chonos during the earthquake, some islands were said to have vanished while shorelines at others emerged. The southernmost written evidence of land-level changes in 1837 comes from San Rafael Fjord $\left(46.60^{\circ} \mathrm{S}\right)$, at the southern end of the 1960 rupture (Fig. 1b). Exploring the fjord in 1857, Vidal Gormaz found the remains of a forest partially submerged on the floor of the fjord. He inferred that the 1837 earthquake had lowered the trees. These trees were likely the same ones that were studied much later by Reed et al. (1988), who arrived at a similar conclusion by counting the annual growth rings of one of the drowned trees. In 1871, explorer Enrique Simpson resurveyed the fjord (ㅌ) Fig. S1), described the drowned forest again, and reached the same conclusion. However, in a subsequent report in 1873 Simpson retracted his earlier inference that the 1837 earthquake submerged the forest only once, concluding that subsidence repeated over time.

The 1837 tsunami is much better known from its effects on distant shores, in Hawaii, Japan, and Polynesia, than from those near its source. Chilean accounts report unusual sea movements, including a slight withdrawal and anomalous tides, in Concepción; a bay that usually amplifies tsunamis. Near Ancud, which faces inland waters, sea water was observed $700 \mathrm{~m}$ inland in an unidentified low-lying area, although it was not reported to have run inland in most places near the town. In the Pudeto Estuary and Chacao Channel (Fig. 1b and (E) Fig. S1a), uncommon surges left algae and shellfish stranded, swept from their bed. One of the whalers' accounts may refer to the southernmost known effects of the 1837 tsunami. At Lemu Island, one month after the 1837 earthquake, Captain Coste noted that "A great quantity of trees, torn up by the roots and carried to sea in those shocks, were to be seen along the shore." A brief analysis of the characteristics of the 1837 tsunami on the Chilean coast, including the computed tide curve of the day of the earthquake (ㄹ) Text S2) and some hypotheses to explain its relatively modest local effects (ㅌ) Text S4), are offered in the electronic supplement. 
(a)

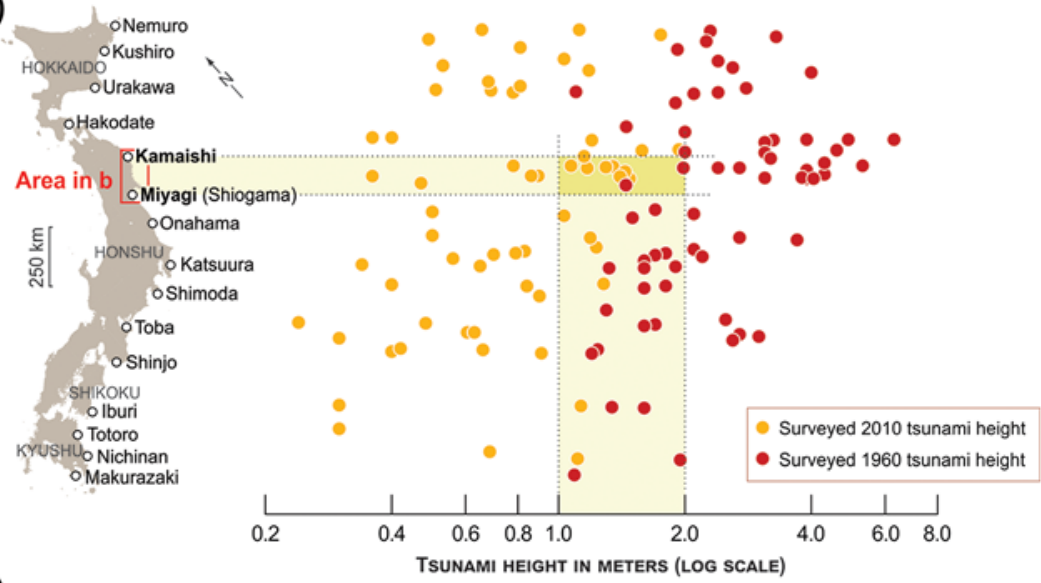

(b)

"In the night of October 11 [8 November] tsunami waves flooded onto [the] residential area of Kamaishi City, and people were worried and kept watch."



"The year 8 of Tenpo, month 10th and day 11 th [8 November, 1837], at the time of Yoru-Kokonotsu-Han [1 a.m.] a tsunami came and the salmon traps in the river Imaizumi were pushed and broken apart violently..

The dikes surrounding the salt works around the towns of Akasaki and Ofunato were breached and the shed for pots lused to cook salt] was also greatly damaged.

Around two thousands straw bags of salt were carried out by the tsunami, it was a huge lost.

There are lesser damages in the bay of the Otomo and Osabe towns...

When there is a large earthquake there is tsunami, and it is strange that a tsunami occurred without an earthquake.

The water raised everywhere between Obashi and Ohashi. The water did

"The same year, month 10th, day 11th [8 November, 1837], since the time of Kokonotsu night [midnight] a large tsunami came in lat Onagawal and caused panic on the people. This time the tsunami came without an earthquake."

"The day 11 th of month 10th [8 November] the tide flooded Motoyoshi, in Kesen county and the coast of Ojika and Miyagi counties damaging rice fields"

Figure 4. Comparison of the effects of the 1960 and 2010 Chilean tsunamis with those of the 1837 Chile tsunami along the Japanese coast. (a) Surveyed heights reached by the 1960 tsunami (Committee for Field Investigation of the Chilean Tsunami of 1960, 1961), and those of the 2010 tsunami (Tsuji et al., 2010). Shaded area shows the intersection between the 1- to 2-m range of heights and the latitudinal range of the 1837 chronicles in (b). (b) Japanese chronicles describing the effects of the 1837 tsunami on the coastal towns between Kamaishi and Miyagi (full records and details are in (E) the electronic supplement). Based on the reported effects, the 1837 tsunami was probably between 1 and $2 \mathrm{~m}$ high on that coast. This range overlaps the highest waves of the 2010 tsunami, triggered by an $M_{\mathrm{w}} 8.8$ earthquake, and the lowest of the 1960 tsunami $\left(M_{\mathrm{w}}\right.$ 9.5). If so, the size of the 1837 earthquake was likely between $M_{\mathrm{w}} 8.8$ and 9.5, in agreement with the tsunami magnitude of $91 / 4$ estimated by Abe (1979), which implies nearly half the seismic moment of the 1960 mainshock. The color version of this figure is available only in the electronic edition.

In contrast, in the Gambier Islands (French Polynesia), the 1837 tsunami reached at least $2 \mathrm{~m}$ and produced strong currents and extensive inundation (Dumoulin, 1840). In the Samoan Islands, the tsunami attained $\sim 1 \mathrm{~m}$ height and produced hours-long flooding and ebb tides (Dumoulin, 1840; Wilkes, 1845). The tsunami had catastrophic results in the Hawaiian archipelago, particularly in Hilo, where it reached a height of $6 \mathrm{~m}$, with loss of life and destruction of houses (Rooke, 1839; Coan, 1882).
RECORD 16 RECORD 17

RECORD 18

RECORD 19

According to four Japanese chronicles that were translated and analyzed as a part of this study (Fig. 4 and (E) Text S1), the 1837 tsunami affected towns on the northeast coast of Honshu, between Kamaishi and Miyagi (Shiogama), located in today's Iwate and Miyagi prefectures (Fig. 4a). The tsunami flooded the residential area of Kamaishi. It destroyed salmon traps in the Imaizumi River. In Akasaki and Ofunato, salt-evaporation works and a salt storehouse were damaged and 2000 bales of salt were lost. Although the damage was less in Otomo and Osabe, the water inundated the lower neighborhoods there. After midnight, the 1837 tsunami caused great disturbance in Onagawa and flooded Motoyoshi and Miyagi, where it damaged rice fields (Fig. 4b). Interestingly, two of the four writers wonder about this peculiar case of a tsunami without an earthquake. Considering these reported effects, the 1837 tsunami likely reached minimum heights of 1-2 m in Japan. Based on the $6 \mathrm{~m}$ reported in Hawaii, the $\sim 1-2 \mathrm{~m}$ range for Japan seems conservative. This range of likely tsunami heights in 1837 falls between the highest levels reached by the 2010 tsunami and the lowest in 1960 along the same stretch of the Japanese coast (Fig. 4a). According to the robust relationship inferred between the magnitudes of Chilean earthquakes and the amplitudes of their tsunamis in Japan (Carvajal et al., 2017), a range of $\sim 1-2 \mathrm{~m}$ suggests that the magnitude of the 1837 earthquake was likely between $M_{\mathrm{w}} 8.8$ and 9.5. This rough estimation also agrees with the tsunami magnitude of $91 / 4$ assigned to the 1837 event by Abe (1979).

Synthesis, Modeling, and Discussion

\section{Source of the 1737 Earthquake}

Both written and geologic evidence all point to a source of the 1737 earthquake located south of Concepción and north of Chiloé, namely the northern half of the region that ruptured in 1960. Accounts indicate that the 1737 earthquake was destructive along a $640-\mathrm{km}$ stretch of south-central Chile, between Concepción and Castro, producing the greatest destruction roughly midway between the two, at Valdivia. Geology helps to constrain the location of the strongest 1737 shaking within this stretch. Shaking triggered slope failures in Villarrica, Calafquén, and Riñihue lakes (Moernaut et al., 2014), all located roughly at the latitude of Valdivia, but it did not 
produce failures in the Gulf of Reloncaví (St-Onge et al., 2012) or at Cocotué (Cisternas et al., 2017), both at the latitude of Ancud, in northern Chiloé.

The great north-south extent of the 1737 earthquake effects suggests a megathrust source. But, if so, how can such a large megathrust earthquake be reconciled with the apparent lack of a tsunami in Chile and Japan? The absence of a tsunami could imply that the 1737 source did not occur at the interface between the Nazca and South America plates, but instead was on a fault within one of those plates. Yet, it is difficult to explain its large extent by an intraplate rupture, as they are usually relatively short, in both extent and duration, and their shaking seems to attenuate rapidly along the strike of the subduction zone (Moernaut et al., 2014). Examples of these spatially focused intraplate events are the 1939 Chillán earthquake, which ruptured deeper than the plate interface within the subducted Nazca plate (Beck et al., 1998), the shallow upper-plate events of Aysén in 2007, associated with the Liquiñe-Ofqui fault (Lange et al., 2008) and Las Melosas earthquake of 1958, linked to the Andean folding around Santiago (Alvarado et al., 2009). Taking all these factors into account, a more plausible explanation is that the 1737 earthquake resulted from a deep rupture in the megathrust, thus explaining the lack of tsunami reports, the strong shaking in the Andean lakes, and the large spatial extent of shaking. As shown by Carvajal et al. (2017), a deep rupture along the Chilean megathrust would produce strong shaking and favor uplift of the land rather than beneath the sea, thus producing a small tsunami. This sort of long and deeper-than-average rupture was inferred for the 1906 central Chile earthquake on the basis of the strong shaking, coastal uplift, and a small tsunami (Carvajal et al., 2017). Thus, we believe that the evidence favors a deep source along the northern half of the 1960 region for the 1737 earthquake.

\section{Source of the 1837 Earthquake and Tsunami}

The rupture of the 1837 earthquake clearly differed from those of the 1737 and 1960 earthquakes. It was mainly concentrated in the southern half of the 1960 region with a length between 550 and $800 \mathrm{~km}$ as evidenced by land-level changes or by shaking. Nonetheless, the damage in Valdivia and the triggering of turbidites in lakes within the northern half of the 1960 region ( $250 \mathrm{~km}$ north of Chiloé) suggest that the 1837 rupture propagated into the northern fault area where substantial slip occurred in 1960. Alternatively, a rupture confined to the south might have produced strong motions in the north owing to focusing, rupture propagation, or site effects. A further possibility, also in agreement with the evidence, is that the southern rupture in 1837 extended into the northern half of the 1960 region but only along the deeper part of the megathrust. As in 1737, the extension of a deep rupture to the north in 1837 could explain the lacustrine turbidites, the destruction of Valdivia, and the lack of tsunami reports on that portion of the coast.
This inferred deep slip at the latitude of Valdivia in 1837 would not conflict with the large slip during the 1960 mainshock, as the latter occurred mainly on the shallower plate interface (Wang et al., 2007; Moreno et al., 2009), but it might conflict with the large-scale deep slip hypothesized to explain the slow giant precursor in 1960 (Kanamori and Cipar, 1974; Cifuentes and Silver, 1989). However, the source location of this hypothetical event, if real, is still a matter of debate.

Land-Level Changes and Tsunami Size Constrain the Depth of 1837 Slip

Unlike the 1960 event, which was characterized by coastal subsidence along its source area (Plafker and Savage, 1970), the 1837 earthquake uplifted the coast. In northern Chiloé, the 1837 accounts of strong shaking and a tsunami in the inland sea around Ancud agree well with the geologic evidence of slope failures (St-Onge et al., 2012; Cisternas et al., 2017) and of a medium-size tsunami (Cisternas et al., 2017; Kempf et al., 2017). However, this congruent evidence contrasts sharply with the absence of geologic evidence for coastal subsidence in 1837 at this latitude (Cisternas et al., 2005; Garrett et al., 2015). Evidence from trees killed by the 1960 subsidence but that had survived 1837 also argues against subsidence on the coast in 1837 (Bartsch-Winkler and Schmoll, 1993; Cisternas et al., 2005). Absence of coastal subsidence in 1837 could imply, besides differences in size with the 1960 event, a difference in the distribution of the slip in the dip direction.

Moernaut et al. (2014) suggest that slip in 1837 was largely concentrated in the southern half of the 1960 region, which would explain the relatively lower slip inferred for that region later in 1960. The same authors further propose that most of the slip in 1837 occurred on the shallow part of the megathrust, which would also explain both the 1960 slip distribution and the thermal model results of Volker et al. (2011). The inference of a shallow dislocation seems also to be in agreement with the large 1837 tsunami observed in Hawaii and Japan.

We tested the feasibility of the shallow rupture proposed by Moernaut et al. (2014) by comparing the evidence of both land-level changes and tsunami size with those predicted by hypothetical dislocations at different depths on the plate interface (Fig. 5). We found that instead of a narrow shallow rupture, only a wide one, extending from the buried trench to about $60 \mathrm{~km}$ depth, predicts land-level changes and tsunami amplitudes compatible with all of the evidence from 1837 . The rupture of only a shallow part of the fault, as proposed by Moernaut et al. (2014; Fig. 5a,b), although yielding a large tsunami in the Pacific, including high amplitudes in Hawaii and Japan, raises and lowers locations that actually moved in the opposite vertical sense in 1837. The rupture of only the intermediate portion of the fault (Fig. 5c) fails to produce the pattern of land-level changes indicated by observations in Lemu and the Chonos, and it does not produce a significant tsunami in Hawaii and Japan. Interestingly, this 

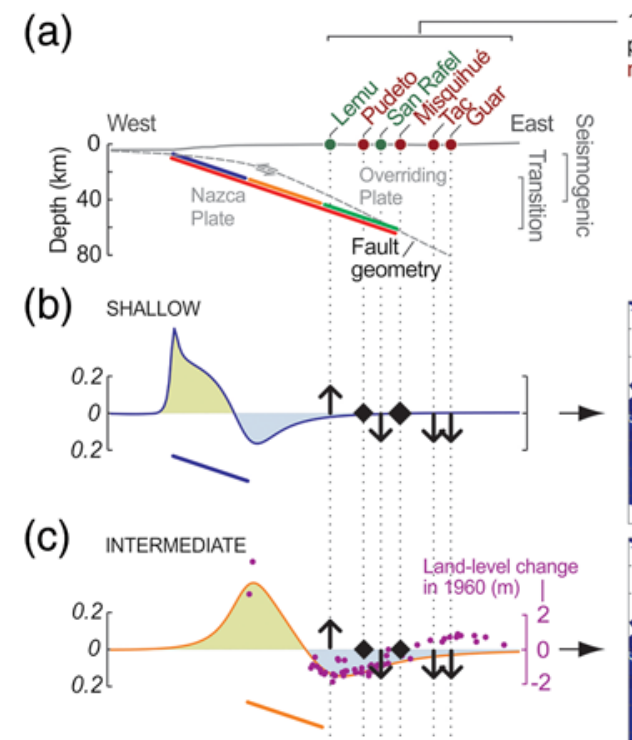

(d) DEEP

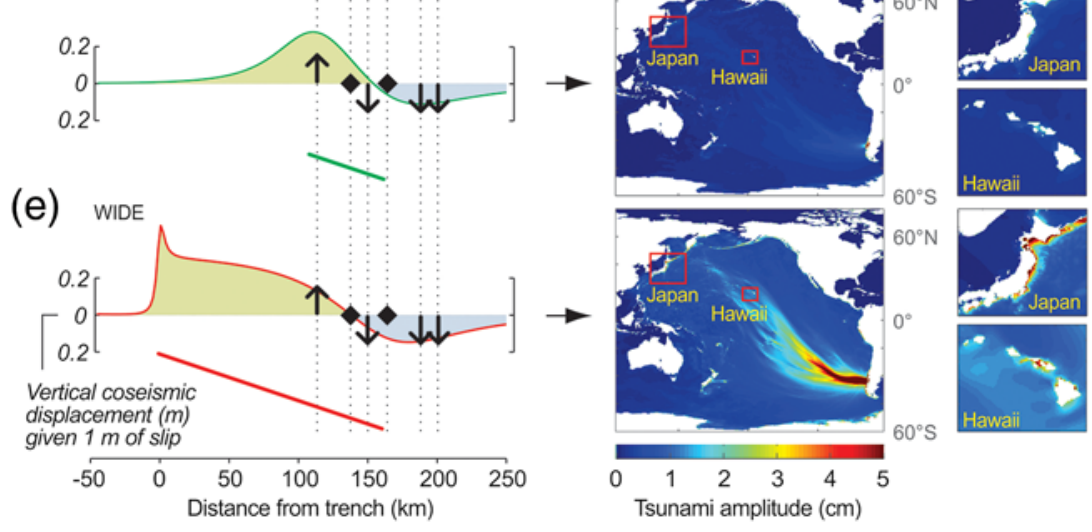

Figure 5. Land-level changes and tsunamis predicted by four hypothetical ruptures compared with the 1837 and 1960 land-level changes projected onto a cross section through Isla Chiloé. (a) Plate-boundary profile, including the interplate geometry and seismogenic and transition zones based on thermal models (modified from Volker et al., 2011). The actual curved fault is represented as a simple plane dipping $18.5^{\circ}$. The plane is equally divided into three parts: (b) shallow, (c) intermediate, and (d) deep. (e) A wide rupture combines these three. Sites with historical or geologic evidence are projected onto the profile line. Predicted tsunami amplitudes through the Pacific are shown graphically at right of each hypothetical rupture, including close ups of the amplitudes in Japan and Hawaii. The color version of this figure is available only in the electronic edition.

\section{Implications of a Wide Rupture in} 1837

A wide rupture in 1837 in the southern half of the 1960 region as inferred above would call into question the hypothesis that the seismogenic zone always narrows to the south as a consequence of the thermal regime controlled by the age variations of the Nazca plate (Wang et al., 2007; Volker et al., 2011). However, it would be in accord with the proposal of a constant width based on thermal models that consider the effects of the hydrothermal circulation within the oceanic crust and the frictional heating on the plate interface (Rotman and Spinelli, 2014). In these models, hydrothermal circulation cools the younger and warmer subducting lithosphere in the south while frictional heating warms the older and cooler lithosphere in the north. The combined effects produce a remarkably constant thermal state of the plate interface along strike, implying a uniform $200 \mathrm{~km}$ wide seismogenic zone all along the 1960 region.

A wide rupture in 1837 also has implications for the current tectonic deformation of the 1960 region. GPS measurements conducted over the last decades along the 1960 rupture area show a pattern in which coastal sites move landward while those located inland, near the Andes, move seaward (Klotz et al., 2001; Khazaradze et al., 2002; Hu et al., 2004). Although this pattern, interpreted as prolonged postseismic deformation by mantle stress relaxation after 1960, is observed all along the 1960 area, the GPS observations exhibit a remarkable southward decrease of the landward velocities along the coast (Wang et al., 2007). Such a decrease could be explained either by a southward narrowing of the 1960 rupintermediate rupture produces a similar pattern of land-level changes to that observed in 1960. A deep fault rupture (Fig. 5d), although its results match well with the 1837 land-level changes, fails to generate a large transpacific tsunami, because vertical deformations are restricted to very shallow water and beneath the land. Thus, it seems that only an earthquake rupturing a wide section down the plate interface is capable of explaining both the sense of coastal landlevel changes and the size of the 1837 tsunami (Fig. 5e). Therefore, taking all the evidence into account, we conclude that the most reasonable and simple explanation is an earthquake produced by a wide rupture, extending from or near the trench to depths of about $60 \mathrm{~km}$ of the plate interface. ture, and a subsequent narrower locked zone, or by a uniformly wide 1960 rupture, all along its extent, but with much less slip in the south. However, the current locking distribution suggests that locking is most pronounced at some asperities that released the highest slip in 1960, implying both some degree of persistence of the major asperities and that the locking varies with time (Moreno et al., 2011). Thus, it seems that the plate interface accumulates slip deficit in a spatially and temporally variable manner toward the next large earthquake. In other words, the zone of accumulated slip, and potentially capable of producing large earthquakes, changes throughout the seismic cycle and perhaps between seismic cycles. 
If the uplift at Lemu Island, observed just one month after the 1837 earthquake, was indeed coseismic, our conclusion of a rather wide 1837 rupture supports the hypothesis of a temporal evolution of the seismogenic zone. Regardless of the simplicity of our modeling, to raise Lemu Island and simultaneously produce a large transpacific tsunami, the slip in 1837 must have extended from or near the trench to depths significantly deeper than the down-dip limit of the seismogenic zone currently inferred from GPS observations. Although other possibilities could explain the evidence of coastal uplift in 1837 (e.g., a localized slip patch beneath or eastward Lemu Island, rapid after slip, slip in a foreshock and/or aftershock, and/or splay faulting), by applying the law of parsimony to the sum of available data, the simplest explanation is that of a wide rupture in 1837.

\section{Conclusions}

New documentary findings together with previously reported geologic evidence provide the opportunity to analyze the historical seismic sequence preceding the giant 1960 earthquake and infer relevant information about the seismogenic zone of the subduction thrust in south-central Chile.

There are significant differences in the along-strike and depth distribution of the ruptures in the 1737, 1837, and 1960 earthquakes. While the 1737 rupture likely occurred in the northern half of the 1960 region, on a narrow and deep portion of the subduction thrust, the 1837 rupture took place mainly in the southern half and most likely slipped over a wide range of depth on the fault.

Because modeling of geodetic observations supports a current southward narrowing of the seismogenic zone along the 1960 region, the inference of a wide southern rupture in 1837 strongly suggests a significant temporal dependence of the width of the seismogenic zone along this region. While challenging some assumptions about the thermal and tectonic processes occurring along the megathrust, this time-dependent seismogenic zone probably helps to explain the evident variability in both size and location of the great megathrust earthquakes that have struck this region over the last five centuries, as evidenced by written history, and through millennia, as inferred from paleoseismological studies.

\section{Data and Resources}

Primary written records of the 1737 and 1837 earthquakes used in this study were physically collected in the historic archives of Archivo Nacional in Chile (www.archivonacional.cl, last accessed October 2017), Archivo de la Nación in Peru (http://agn.gob.pe, last accessed October 2017), Archivo General de Indias in Spain (www.mecd.gob.es, last accessed October 2017), and in the archives of the Peabody Essex (www.pem.org, last accessed October 2017), Falmouth (http://museumsonthegreen.org, last accessed October 2017), and New Bedford (www.whalingmuseum.org, last accessed October 2017) whaling museums in New England, U.S.A.
Japanese original chronicles were excerpted from Tokyo Daigaku Jishin Kenkyusho (University of Tokyo, Earthquake Research Institute) (1989). Shinshu Nihon jishin shiryo (Newly collected materials on historical earthquakes in Japan). All records used in this article are available to the public.

\section{Acknowledgments}

This work was funded by Chile's Fondo Nacional de Desarrollo Científico y Tecnológico (FONDECYT) project 1150321. Additional support was provided by the Iniciativa Científica Milenio (ICM) through Grant Number NC160025 "Millennium Nucleus CYCLO: The Seismic Cycle Along Subduction Zones." R. W. and L. L. E. were supported through National Science Foundation (NSF) Grants EAR-1145170 and EAR-1624542. Initial versions of the article were greatly improved by reviews from B. Atwater. Special thanks to M. Moreno, who gave insightful and constructive comments. The authors also acknowledge the suggestions provided by an anonymous reviewer

\section{References}

Abe, K. (1979). Size of great earthquakes of 1837-1974 inferred from tsunami data, J. Geophys. Res. 84, 1561-1568.

Alvarado, P., S. Barrientos, M. Sáez, M. Astroza, and S. Beck (2009). Source study and tectonic implications of the historic 1958 Las Melosas crustal earthquake, Chile, compared to earthquake damage, Phys. Earth Planet. In. 175, 26-36.

Angermann, D., J. Klotz, and C. Reigber (1999). Space-geodetic estimation of the Nazca-South America Euler vector, Earth Planet. Sci. Lett. 171, 329-334

Atwater, B., M. Cisternas, E. Yulianto, A. Prendergast, K. Jankaew, A. Eipert, S. Fernando, I. Tejakusuma, L. Schiappacasse, and Y. Sawai (2013). The 1960 tsunami on beach-ridge plains near Maullín, Chile: Landward descent, renewed breaches, aggraded fans, multiple predecessors, Andean Geol. 40, 393-418.

Atwater, B., S. Musumi-Rokkaku, K. Satake, Y. Tsuji, K. Ueda, and D. Yamaguchi (2005). The orphan tsunami of 1700: Japanese clues to a parent earthquake in North America, U.S. Geol. Surv. Profess. Pap. 1707, 133 p.

Barrientos, S., and S. Ward (1990). The 1960 Chile earthquake: Coseismic slip from surface deformation, Geophys. J. Int. 103, 589-598.

Bartsch-Winkler, S., and H. Schmoll (1993). Evidence for late Holocene relative sea-level fall from reconnaissance stratigraphical studies in an area of earthquake subsided intertidal deposits, Isla Chiloé, southern Chile, in Tectonic Controls and Signatures in Sedimentary Successions, L. E. Frostwick and R. J. Steel (Editors), International Association of Seismologists, Blackwell Scientific Publications, Oxford, England, 91-108.

Beck, S., S. Barrientos, E. Kausel, and M. Reyes (1998). Source characteristics of historic earthquakes along the central Chile subduction zone, J. S. Am. Earth Sci. 11, 115-129, doi: 10.1016/S0895-9811(98)000054.

Carvajal, M., and A. Gubler (2016). The effects on tsunami hazard assessment in Chile of assuming earthquake scenarios with spatially uniform slip, Pure Appl. Geophys. 173, 3693-3702.

Carvajal, M., M. Cisternas, A. Gubler, P. Catalán, P. Winckler, and R. Wesson (2017). Reexamination of the magnitudes for the 1906 and 1922 Chilean earthquakes using Japanese tsunami amplitudes: Implications for source depth constraints, J. Geophys. Res. 122, 4-17, doi: 10.1002/ 2016JB013269.

Cifuentes, I. (1989). The 1960 Chilean earthquakes, J. Geophys. Res. 94, $665-680$.

Cifuentes, I., and P. Silver (1989). Low-frequency source characteristics of the great 1960 Chilean earthquake, J. Geophys. Res. 94, 643-663. 
Cisternas, M., B. F. Atwater, F. Torrejón, Y. Sawai, G. Machuca, M. Lagos, A. Eipert, C. Youlton, I. Salgado, T. Kamataki, et al. (2005). Predecessors of the giant 1960 Chile earthquake, Nature 437, 404-407.

Cisternas, M., E. Garrett, R. Wesson, T. Dura, and L. Ely (2017). Unusual geologic evidence of coeval seismic shaking and tsunamis shows variability in earthquake size and recurrence in the area of the giant 1960 Chile earthquake, Mar. Geol. 385, 101-113.

Cisternas, M., F. Torrejón, and N. Gorigoitia (2012). Amending and complicating Chile's seismic catalog with the Santiago earthquake of 7 August 1580, J. S. Am. Earth Sci. 33, 102-109.

Clark, A. H. (1887). History and present condition of the fishery, in History and Methods of the Fisheries, G. B. Goode (Editor), The Fisheries and Fishery Industries of the United States, Section V, Vol. II, Government Printing Office, Washington, D.C., 3-128.

Coan, T. (1882). Life in Hawaii; An Autobiographic Sketch of Mission Life and Labors (1835-1881), Anson Randolph \& Company, New York, New York.

Committee for Field Investigation of the Chilean Tsunami of 1960 (1961). Report on the Chilean tsunami of May 24, 1960, as observed along the coast of Japan, Maruzen Co., Ltd., Tokyo, Japan 397 pp.

Dumont d'Urville, J. (1842). Voyage au Pôle sud et dans l'Océanie sur les corvettes "l'Astrolabe" et "la Zélée", exécuté par ordre du Roi pendant les années 1837-1838-1839-1840, Gide éditeur, Paris, France (in French).

Dumoulin, C. (1840). Coincidence de date de quelques mouvements extraordinaires de la mer, observés dans l'Océanie, avec le tremblement de terre qui en 1837 renversa la ville de Valdivia au Chili, Extrait dune lettre de M. Dumoulin à M. Arago, C. R. Acad. Sci. 21, 835-837 (in French).

Eaton, J., D. Richter, and W. Ault (1961). The tsunami of May 23, 1960, on the Island of Hawaii, Bull. Seismol. Soc. Am. 51, 135-157.

Ely, L., M. Cisternas, R. Wesson, and T. Dura (2014). Five centuries of tsunamis and land-level changes in the overlapping rupture area of the 1960 and 2010 Chilean earthquakes, Geology 42, 995-998.

Garrett, E., I. Shennan, S. Woodroff, M. Cisternas, P. Hocking, and P. Gulliverd (2015). Reconstructing paleoseismic deformation, 2: 1000 years of great earthquakes at Chucalén, south central Chile, Quaternary Sci. Rev. 113, 112-122.

Greve, E. (1948). La Vida Marina en su relación con la pesca y la caza, Rev. Hist. Geog. 1725, 1-23 (in Spanish).

Hu, Y., K. Wang, J. He, J. Klotz, and G. Khazaradze (2004). Three-dimensional viscoelastic finite element model for postseismic deformation of the great 1960 Chile earthquake, J. Geophys. Res. 109, no. B12403, doi: 10.1029/2004JB003163.

Kanamori, H., and J. Cipar (1974). Focal process of the Great Chilean earthquake May, 22, 1960, Phys. Earth Planet. In. 9, 128-136.

Kempf, P., J. Moernaut, M. Van Daele, W. Vandoorne, M. Pino, R. Urrutia, and M. De Batist (2017). Coastal lake sediments reveal 5500 years of tsunami history in south central Chile, Quaternary Sci. Rev. 161, 99-116.

Khazaradze, G., K. Wang, J. Klotz, Y. Hu, and J. He (2002). Prolonged postseismic deformation of the 1960 great Chile earthquake and implications for mantle rheology, Geophys. Res. Lett. 29, doi: 10.1029/ 2002GL015986.

Klotz, J., A. Abolghasem, G. Khazaradze, B. Heinze, T. Vietor, R. Hackney, K. Bataille, R. Maturana, J. Viramonte, and R. Perdomo (2006). Longterm signals in the present-day deformation field of the central and southern Andes and constraints on the viscosity of the Earth's upper mantle, in The Andes-Active Subduction Orogeny, Frontiers in Earth Sciences, O. Oncken, G. Chong, G. Franz, P. Giese, H.-J. Götze, V. Ramos, M. Strecker, and P. Wigger (Editors), Springer, Berlin, Heidelberg, Germany, 65-89.

Klotz, J., G. Khazaradze, D. Angermann, C. Reigber, R. Perdomo, and O. Cifuentes (2001). Earthquake cycle dominates contemporary crustal deformation in central and southern Andes, Earth Planet. Sci. Lett. 193, 437-446.

Lange, D., J. Cembrano, A. Rietbrock, C. Haberland, T. Dahm, and K. Bataille (2008). First seismic record for intra-arc strike-slip tectonics along the Liquiñe-Ofqui fault zone at the obliquely convergent plate margin of the southern Andes, Tectonophysics 455, 14-24.
Liu, P., S. Woo, and Y. Cho (1998). Computer programs for tsunami propagation and inundation, Technical Report, Cornell University, $111 \mathrm{pp}$.

Lomnitz, C. (1970). Major earthquakes and tsunamis in Chile during the period 1535 to 1955, Geol. Rundsch. 59, 938-960.

Melgar, D., S. Riquelme, X. Xu, J. Baez, J. Geng, and M. Moreno (2017). The first since 1960: A large event in the Valdivia segment of the Chilean subduction zone, the 2016 M 7.6 Melinka earthquake, Earth Planet. Sci. Lett. 474, 68-75.

Moernaut, J., M. Van Daele, K. Heirman, K. Fontijn, M. Strasser, M. Pino, R. Urrutia, and M. de Batist (2014). Lacustrine turbidites as a tool for quantitative earthquake reconstruction: New evidence for a variable rupture mode in south central Chile, J. Geophys. Res. 119, 1607-1633.

Moreno, M., D. Melnick, M. Rosenau, J. Bolte, J. Klotz, H. Echtler, J. Baez, K. Bataille, M. Bevis, and H. Hase, et al. (2011). Heterogeneous plate locking in the south-central Chile subduction zone: Building up the next great earthquake, Earth Planet. Sci. Lett. 305, 413-424.

Moreno, M. S., J. Bolte, J. Klotz, and D. Melnick (2009). Impact of megathrust geometry on inversion of coseismic slip from geodetic data: Application to the 1960 Chile earthquake, Geophys. Res. Lett. 36, L16310, doi: 10.1029/2009GL039276.

Okada, Y. (1985). Surface deformation due to shear and tensile faults in a half space, Bull. Seismol. Soc. Am. 75, 1135-1154.

Pereira Salas, E. (1971). Los primeros contactos entre Chile y los Estados Unidos, Editorial Andrés Bello, Santiago, Chile, 1778-1809 (in Spanish).

Plafker, G., and J. Savage (1970). Mechanisms of Chilean earthquakes of May 21 and May 22, 1960, Geol. Soc. Am. Bull. 81, 1001-1030.

Reed, D., R. Muir-Wood, and J. Best (1988). Earthquakes, rivers and ice: Scientific research at the Laguna San Rafael, southern Chile, 1986, Geogr. J. 154, 392-405.

Rooke, T. (1839). Notice of remarkable agitations of the sea at the Sandwich Islands, on the 7th November 1837, Edinburgh New Philos. J. 27, 141144.

Rotman, H., and G. Spinelli (2014). Remarkably consistent thermal state of the south central Chile subduction zone from $36^{\circ} \mathrm{S}$ to $45^{\circ} \mathrm{S}, \mathrm{J}$. Geophys. Res. 119, doi: 10.1002/2013JB010811.

Ruiz, S., M. Moreno, D. Melnick, F. del Campo, P. Poli, J. C. Baez, F. Leyton, and R. Madariaga (2017). Reawakening of large earthquakes in south central Chile: The $2016 \mathrm{M}_{\mathrm{w}}$ 7.6 Chiloé event, Geophys. Res. Lett. 44, doi: 10.1002/2017GL074133.

Sievers, H. (1963). The seismic sea wave of 22 May 1960 along the Chilean coast, Bull. Seismol. Soc. Am. 53, 1125-1190.

St-Onge, G., E. Chapron, S. Mulsow, M. Salas, M. Viel, M. Debret, A. Foucher, T. Mulder, T. Winiarski, M. Desmet, et al. (2012). Comparison of earthquake-triggered turbidites from the Saguenay (eastern Canada) and Reloncavi (Chilean margin) Fjords: Implications for paleoseismicity and sedimentology, Sediment. Geol. 243, 89-107.

Torrejón, F., M. Cisternas, and A. Araneda (2004). Efectos ambientales de la colonización española desde el río Maullín al archipiélago de Chiloé, sur de Chile, Rev. Chil. Hist. Nat. 77, 661-677 (in Spanish).

Tsuji, Y., K. Ohtoshi, S. Nakano, Y. Nishimura, K. Fujima, F. Imamura, T. Kakinuma, Y. Nakamura, K. Imai, K. Goto, et al. (2010). Field investigation on the 2010 Chilean earthquake tsunami along the comprehensive coastal region in Japan, Coast. Eng. 66, 1346-1350 (in Japanese).

Ueda, K., and T. Usami (1990). Number of earthquakes in historical records, Hist. Earthq. (Rekishi Jishin) 6, 181-187 (in Japanese).

Volker, D., I. Grevemeyer, M. Stipp, K. Wang, and J. He (2011). Thermal control of the seismogenic zone of southern central Chile, J. Geophys. Res. 116, no. B10305, doi: 10.1029/2011JB008247.

Wang, K., Y. Hu, M. Bevis, E. Kendrick, R. Smalley, R. Vargas, and E. Lauria (2007). Crustal motion in the zone of the 1960 Chile earthquake: Detangling earthquake-cycle deformation and forearc-sliver translation, Geochem. Geophys. Geosys. 8, no. Q10010, doi: 10.1029/ $2007 \mathrm{GC} 001721$.

Wang, X. (2009). User Manual for COMCOT Version 1.7 (First Draft), Cornell University, New York, New York, 59 pp. 
Watanabe, H. (1998). Comprehensive List of Destructive Tsunamis to Hit the Japanese Islands, Univ. Tokyo Press, Tokyo, Japan (in Japanese).

Wilkes, C. (1845). Narrative of the United States Exploring Expedition during the Years 1838, 1839, 1840, 1841, 1842, C. Sherman, Philadelphia, Pennsylvania.

Xu, W. (2017). Finite-fault slip model of the 2016 M 7.5 Chiloé earthquake, southern Chile, estimated from Sentinel-1 data, Geophys. Res. Lett. 44, doi: 10.1002/2017GL073560.

Escuela de Ciencias del Mar

Pontificia Universidad Católica de Valparaíso

Avenue Altamirano 1480

Valparaiso, Chile

marco.cisternas@pucv.cl

matias.carvajal.ramirez@gmail.com

nga2043@gmail.com

(M.C., M.C., N.G.)
U.S. Geological Survey

Denver Federal Center

PO Box 25046, MS-966

Denver, Colorado 80225

rwesson@gmail.com

(R.W.)

Department of Geological Sciences

Central Washington University

Ellensburg, Washington 98926-7418

ely@geology.cwu.edu

(L.L.E.) 